\title{
NARRATIVES ABOUT DISPLACEMENT AND STIGMATIZATION OF IDENTITIES
}

\author{
Maria do Carmo Leite de Oliveira, \\ Carla Mirelle de Oliveira Matos Lisboa \\ Pontifical Catholic University of Rio de Janeiro \\ 225 Rua Marquês de São Vicente, 22453-900 Gávea, Rio de Janeiro, Brazil
}

\begin{abstract}
The displacement of people who leave their home to live in the streets is one of the social dramas commonly found in large urban areas. Despite forming a heterogeneous population group, these people are seen by society as one homogenous crowd, grouped together based on the generalizations of negative categorizations attributed to them. This article analyzes the displacement storytelling of a woman who lost her house to heavy rainstorms, which forced her to go live in the streets with her seven youngest children. Based on the concepts of membership categorization analysis, stigma and talking back, we aim to investigate how this former street dweller refutes the stigmatized identities that she knows are attributed to her, as well as how she claims an alternative identity. Her narrative was produced in the context of an interview for research on life stories. The results show that the storyteller seeks to build a coherent narrative for her own self by adopting a belief system to organize her life story and by providing explanations to the events in her life. Accordingly, she blames the street dwellers' deviant behavior on the street environment, and also claims her status as a member of the "family" collection by invoking the dominant discourse on motherhood as an ideal of female fulfillment. Ultimately, this study highlights the importance of knowing the native categories, that is, the categories created by the members of the group whose actions are being studied, which challenge the categories conceived by outsiders.
\end{abstract}

Keywords: conversation analysis theory, discourse, homeless people, stigma, identity, talking back, internal displacement, narratives

\section{INTRODUCTION}

The displacement of people, whether external when crossing a border or internal when leaving an area or one's own home, is one of the contemporary social dramas where people are forced, for a variety of reasons, to abandon their homes, often without the possibility of returning.

Generally speaking, after being displaced, war refugees or people who leave their homes within a territory start being subjected to a stigmatized identity, which only compounds their suffering and makes adapting to the new reality even more difficult.

In today's big cities, one of the most common types of internal displacement is people leaving their homes to live in the streets following natural, economic or psychological adversities. Major urban areas are characterized by a large number of homeless people who, despite living in the same streets we walk on every day, are invisible to society. Some of the negative categorizations attributed to them are lazy, addicted and violent.

In the case of displaced women dwelling in the streets, identity stigmatization is even stronger due to the prevailing discourse on feminine identity. Negative judgments 
are even more severe when these homeless women have children or get pregnant while under such circumstances. Due to the dominant notions surrounding motherhood, they are seen as irresponsible and lacking in childcare capabilities.

This article analyzes the displacement storytelling of a woman who lost her house to a heavy rainstorm. She was forced to live in the streets with her children and got pregnant with her eighth child while in this situation. The narrative was generated based on the Conversation Analysis Theory (Mandelbaum 2013) which states that storytelling is a recognizable activity through which tellers execute a social action. Citing Schegloff (1997: 97), Mandelbaum (2013: 492) reminds us that "the focus on telling also facilitates the observation that with stories, tellers not only relate experiences but simultaneously complain, blame, account, justify and so on". The narrative studied in this paper was produced in the context of a research interview, with the teller in the second position, i.e., responding to the interviewer's requests (Schegloff 1997, Sidnell 2010).

Using an ethnomethodological approach, we aim to analyze how the interviewed negotiates her stigmatized identities - very prevalent in the popular common sense as a homeless person and how she builds herself as an outsider of this group.

Despite the relevance of analyzing homeless people's storytelling in order to examine how they experience and express issues such as inequality and social exclusion (Schneider and Remillard 2013), there are few linguistic studies focused on homeless people's stories. Taking this into account, we aim to fill this gap and contribute to the studies about identity and stigma.

This article is divided into six parts, with the first three outlining the theoretical basis for our analysis. In the first one, we focus on the concepts of identity and category; in the second one, we deal specifically with the "mother" category; in the third one, we present the concepts of stigma and talking back. The fourth section comprises the methodological aspects of this research, and the fifth and sixth describe the results obtained. This article ends with some final considerations.

\section{IDENTITIES AND CATEGORIES}

People do not have a single identity and do not assume permanent positions. Identities are very complex, built through discourse. According to Hall (1992), no identity is fully unified, complete and stable; instead, as meanings and cultural representation systems shift and multiply, we face many possible identities, some of which are contradictory, although we may identify ourselves, at least temporarily, with any one of them.

Based on the concept of "member" as described in ethnomethodology studies (Garfinkel 1967), Sacks (1995) studied the notion of identity from the categorization perspective. According to him, speakers identify themselves and others based on categories of belonging. This concept refers to cultural and linguistic methods or practical reasoning and action (common sense methods) that can be observed in people from any culture or community.

Therefore, according to this perspective, the term "category" describes a culturally shared knowledge, which gives rise to certain expectations associated with these categories. Another important point is the relationship that the author establishes between 
category and inference. For example, when identifying someone as a homeless person, we may infer he or she engages in activities usually associated with unemployment, drinking, drug using, littering, stealing, aggression, etc. The mechanism we use to draw inferences from a certain category was called Membership Inference-rich Representative (MIR) by Sacks (1995).

Still according to the author, categories are not stagnant and should be analyzed based on context. Categories and collections (categories grouped based on affinity of belonging) vary based on the events in a particular talk, as each category holds a number of inferences that organize the common sense of the members in the analyzed community.

Category analysis focuses on how identities are built, expressed, challenged and organized in concrete situations of social talk-in-interaction, that is, through language. Sell and Ostermann (2009:17) argue that category analysis

"does not rely on preexisting categories or categories created by the researcher to explain
what is happening, neither does it fall back on common sense categories. Category analysis,
an analytic approach just like Conversation Analysis, always looks at the social actors'
actions in their sequential and mutually-negotiated contexts. Given its engaged and locally
produced nature, category analysis does not warrant Schegloff's (apud Silverman 1998)
criticism, whereby he states that it is promiscuous, easily reduced to common sense ob-
servations and determined by the researcher's authority".

To summarize: on one hand, categorization ensures societal harmony and simplifies the orientation and contact with people in different situations; on the other, it may contribute to discrimination by creating "identity prisons", which hold negative characteristics for some people (Silverman 1998: 88 apud Juhila 2004: 262).

\section{THE "MOTHER" CATEGORY}

In order to explain the notion of Membership Categorization Device, Sacks (1995) suggests the classic description exercise where the subjects' identities are erased in the sentence "The X cried. The Y picked it up", taken from a child's narrative. According to the author, we infer that $\mathrm{X}$ is a baby and that $\mathrm{Y}$ is their mother based on common sense knowledge about activities associated with mothers and babies. With this example, Sacks demonstrates how the inference model contains a type of cultural knowledge about motherhood: mothers are those who care for the baby, the ones responsible for their wellbeing, etc. This indicates a normative tendency to see the mother as the one who picks up the baby and the father as the one who is not naturally responsible for childcare.

Despite the illustrative force of the example, nowadays we could dispute the unanimity of such an assumption (the "mother" category filling Y), as fathers have also been performing tasks traditionally associated with mothers. However, this does not invalidate Sacks' (1995) thesis and only reinforces the extent to which culture influences categories.

In this context, we think it is relevant to examine the different significations attached to the idea of motherhood over time. In contemporary times, the prevailing notion is that a mother's love is universal, instinctive, and that all women love or should 
love their babies since their conception. This social construction causes many mothers to be judged by themselves and by society when they fail to fit such models. Badinter (1980) tries to deconstruct this myth by showing that motherhood and mothers have not always been represented this way ${ }^{1}$.

Feminist literature has also addressed issues surrounding the motherhood myth. In light of the concept of "gender", introduced by contemporary feminists in Social Sciences studies, motherhood has been discussed in its multiple facets: as a symbol of an ideal of femininity, as a symbol of women's oppression and as a symbol of women's empowerment. This goes to show how the same symbol can have many different interpretations. In the case of motherhood, it is "a symbol constructed historically, culturally and politically that results from the dynamics of power and domination between genders" (Scavone 2001:143).

Despite such notions present in literature, common sense still presumes that children are what gives meaning to a woman's life, that a mother loves her children above everything else and that she is the one responsible for their care and well-being. As a result of this type of dominant discourse, mothers living in the streets are more harshly judged than men, even when they are the fathers to the homeless children.

\section{STIGMA AND TALKING BACK TO STIGMATIZED IDENTITIES}

One of the classic references in stigma studies is Goffman (1963), who identifies three very distinct types of stigma. The first type refers to abominations of the body and physical deformities; the second one comprises individual character flaws (perceived as weak will, dishonesty, domineering or unnatural passions, treacherous and rigid beliefs, mental illness, imprisonment, addiction, alcoholism, unemployment, suicide attempts and radical political behavior); and the third type encompasses the tribal stigma of race, nation, and religion, which may be passed down equally to all members of a family or lineage (Goffman 1963).

The common ground among these types of stigma lies in their sociological characteristics: "an individual who might have been received easily in ordinary social intercourse possesses a trait that can obtrude itself upon attention and turn those of us whom he meets away from him, breaking the claim that his other attributes have on us" (Goffman 1963: 5). The author adds that those who do not move away from the particular expectations at hand are considered normal, and that these stigmas are at the base of many types of discrimination. As stated by Goffman (1963: 5),

"We construct a stigma-theory, an ideology to explain his inferiority and account for the danger he represents, sometimes rationalizing an animosity based on other differences, such as those of social class. We use specific stigma terms such as cripple, bastard, moron in our daily discourse as a source of metaphor and imagery, typically without giving thought to the original meaning."

1 The author argues that these types of discourses started being propagated in the last three decades of the 18th century through medical, theological, philosophical, and pedagogical discourses. She also presents some historical examples from different centuries that illustrate the different significations given to motherhood. 
Still according to the author, "The stigmatized individual exhibits a tendency to stratify his "own" according to the degree to which their stigma is apparent and obtrusive. He can then take up in regard to those who are more evidently stigmatized than himself the attitudes the normals take to him" (Goffman 1963: 107).

As shown by Juhila (2004), individuals with a stigmatized identity recognize the definitions attributed to them, but it is understandably hard to accept such a position (Morgan 2000). This may lead to a controversial relationship with their own stigmatized identity, meaning they may refute it one way or another.

In the same study, the author analyzes how shelter residents deal with their stigmatized identities and how they adopt a critical stance against it through what is known as talking back. This type of refutation also appears in our collected data and is defined by Juhila as:

“(...) always a dialogue with culturally dominant categorizations. It would not exist without dominant meanings. With this as my starting point, I define talking back as consisting of acts which comment on and resist stigmatized identities related to culturally dominant categorizations and which have the function of presenting the difference between one's own self or a group and the dominant definition. Talking back is not characterized so much by a downright denial of the stigmatized identity as by a subtle negotiation which calls into question dominant categorizations and evokes the possibilities of alternative identities" (Juhila 2004: 263).

One analytic tool often used in the talking back negotiation is called account. Through these accounts, conversation participants account for their actions where there may be doubts about what they are doing/saying or about their conduct. In other words, they are explanations, which are very common occurrences in interactions. Garcez (2008: 27) states that "such actions reveal the nature of the constant analysis carried out by participants about their own and others' actions. This way, it is the analyst's role to articulate the analysis that the participants have to show to others (...)".

As pointed out by Vieira, Bezerra and Rosa (2004), besides living in extreme poverty, homeless populations have a delimited social place which is negatively judged by society as a whole and by the working class in particular. Based on this, we speculate that homeless people may be the most stigmatized group of all, as they are only visible to society through the lenses of their misconduct or the filth they leave in the streets.

\section{MATERIALS AND METHODS}

This study was carried out using a qualitative and interpretative (Denzin and Lincoln 2003) methodological approach. Data were generated using an open interview with audio recording. This study considers interviews as a type of discourse, in accordance with Mishler (1986), who argues that interviews are a joint product shaped and organized by what interviewers and interviewees say and the way they speak to each other. Additionally, they state that the interview's plan and design do not necessarily predict the contents of the questions and answers. This leads to a co-construction of meaning during the interview, as discourse is co-constructed and depends on who the interviewer is talking to, the relationship between parties, the interviewer's approach, the way they carry out the conversation/interview and the context in which it is set. 


\section{Context of research}

Street dwelling is one of the consequences of displacement situations in which people, for a variety of reasons, are forced to permanently leave their homes. Many of them do not have enough formal education to enter the job market, cannot leave their children under someone else's supervision and have no minimum structure to get back on their feet. In the state of Rio de Janeiro, the government offers rent assistance (Governo do Rio de Janeiro and Secretaria de Estado de Assistência Social e Direitos Humanos 2016) of up to $\mathrm{R} \$ 500.00$ to families displaced as a result of living in high-risk areas, facing temporary vulnerable circumstances, being victimized by public catastrophes or being affected by public construction works of the Growth Acceleration Program. However, the payment is often much lower than the maximum amount, which is not enough to cover rent in a dignified location. This may contribute to families being forced to live in the streets or in high-risk areas.

Additionally, the homeless population is estimated to grow even more, as on $11 / 04 / 2016$ the state's government announced a plan to withdraw the benefits of nine thousand families displaced from high-risk areas who have still not been placed in the promised housings (Bretas 2016). While Brazil and the state of Rio de Janeiro are indeed on the brink of an economic crisis due to governments spending more than they take in, interrupting basic social welfare programs will punish even more those who already live in extreme poverty conditions.

The interviewee in this article used to live in a high-risk area affected by the heavy rainstorms that took over the cities of Rio de Janeiro and Niterói in 2010. After losing her house, she went to live in a shelter and then in the streets, together with her family. After a while, she managed to rent a small room and get off the streets. The 40 -year-old woman has eight children and is one of the people receiving rent assistance for losing her home.

During her time as a homeless person, our interviewee came in contact with the Turma da Sopa de Niterói (TSN) nonprofit organization, which started to assist her. It was there she met our interviewer and co-author, an associate and volunteer for this NPO, who invited her to participate in a research on life stories. TSN is composed of volunteers and provides food, care, support and conversation opportunities so that homeless or socially vulnerable people have an environment where they can be heard regarding their yearnings for change and where they are able to form relationships based on trust and respect. All the procedures in this NPO aim to help the persons recover their hope and self-esteem.

\section{Generated data}

Before the interview, which had been arranged the previous day, the researcher read an informed consent term out loud to the interviewee. This was done in order to explain the study's objectives, to clear up any possible questions and to obtain her formal consent. The subject signed two copies of the consent term, one for the interviewer, one for herself.

The interview's transcription followed the system described in ethnomethodological conversation analysis, based on the conventions proposed by Jefferson (1974). Furthermore, it was an adaptation of the Talk-in-Interaction in Institutional and Non-institutional Settings research group, coordinated by Prof. Ana Cristina Ostermann, in accordance with 
the conventions described in the Gesprächsanalytisches Transkriptionssystem 2 (GAT2) ${ }^{2}$ document.

The participant's name, as well as the names mentioned by her, were changed for pseudonyms $^{3}$ to ensure anonymity. The recording, which lasts 23 minutes and 43 seconds, took place in the city of Niterói, in the state of Rio de Janeiro, on June 8, 2015. At the time, the interviewee was still living in a small room with her family.

\section{REFUTATIONS TO STIGMATIZED IDENTITIES}

The relevance of the homeless woman's identity may be perceived from the beginning of the interview, as shown in Excerpt 1:

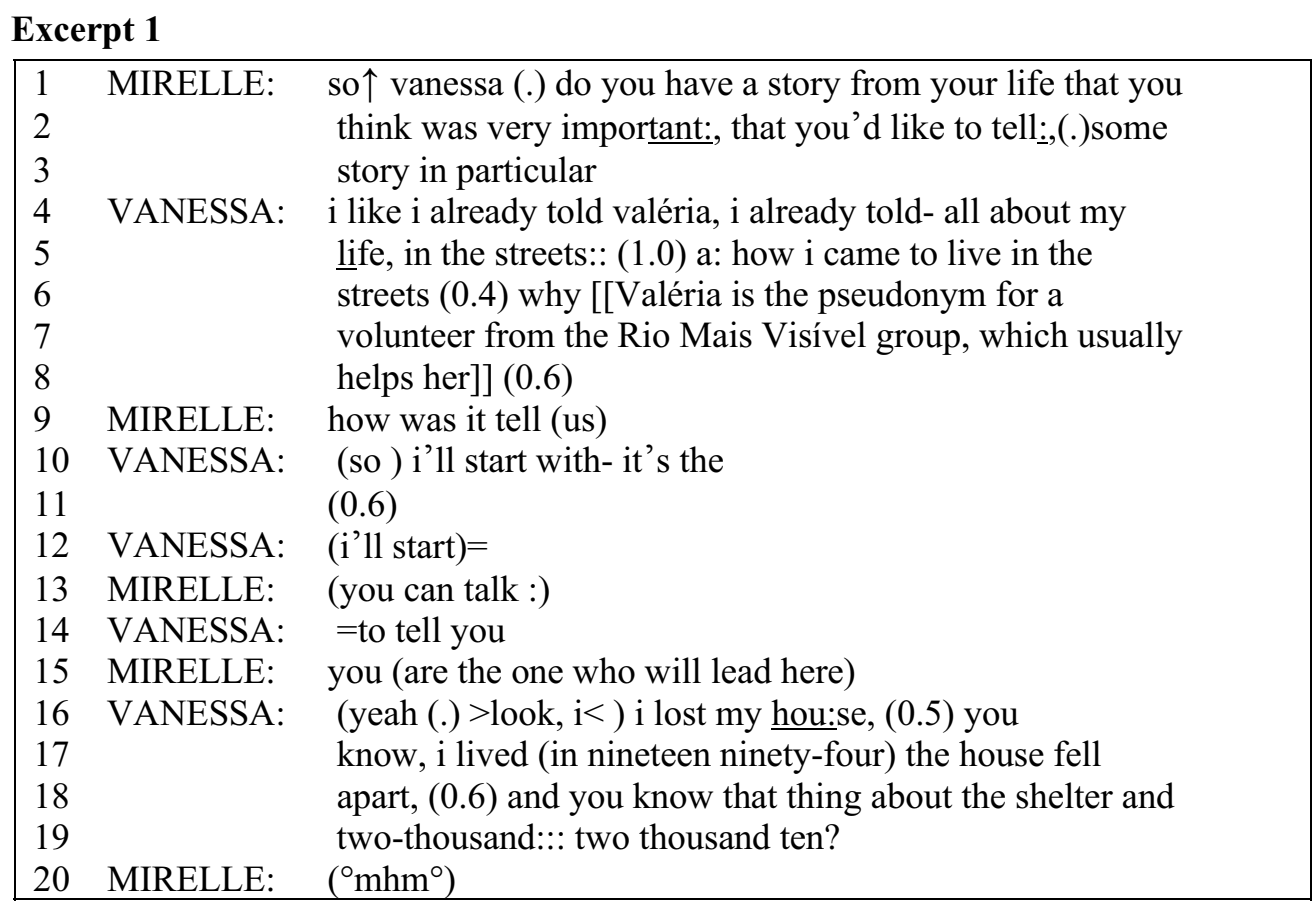

Even though Vanessa was free to choose what to tell regarding her life story, she inferred that the interviewer expected her to tell the story of her displacement to the streets, as stated in lines $4-5$. With a small pause, the narrator opens up a space to a change of turn, possibly waiting for the interviewer to confirm or deny the inference. However, since this space was not filled (line 5), Vanessa continues listing the main topics of the story (how i came to live in the streets $(0.4)$ why). Only after a micropause by the narrator, Mirelle takes her turn to confirm her interest in recording the story of the displacement, which prompts Vanessa to start her storytelling by presenting the cause of the displacement, in lines 16-19 (i lost my hou:se, (0.5) you know, i lived (in nineteen ninety-four the house fell apart).

2 The transcription conventions are listed in an appendix in this article.

${ }^{3}$ Garcez (2002) shows that the practice of giving proper names (either real or pseudonyms) to research participants is used academically by Conversation Analysis (Ethnometodological) studies to identify speakers in texts (transcription and analysis). He also advocates this identification method. 
The relevance of the stigmatized identities appears when Vanessa talks about her life in the streets, listing activities linked to the homeless category, as shown in Excerpt 2.

Excerpt 2

\begin{tabular}{|c|c|c|}
\hline 104 & VANESSA: & but i'll say one thing who. (0.4) who lives in the street is \\
\hline 105 & & not ha- IS HAPPY (0.4) in part (0.9) because the streets \\
\hline 106 & & are really bad the street learns to- teaches you $(0 . \overline{6})$ good \\
\hline 107 & & things $\uparrow$ and $\uparrow$ bad things (0.7) who usually doesn't drink \\
\hline 108 & & ends up drinking, who usually doesn't use drugs uses them \\
\hline 109 & & (0.4) who is not violent $>$ becomes violent $<$ to defend \\
\hline 110 & & themselves \\
\hline 111 & & $(1.8)$ \\
\hline 112 & & you know \\
\hline
\end{tabular}

Vanessa recognizes the stigmatized categories associated with those living in the streets, such as alcoholics, drug addicts, and capable of acts of violence (lines 106-109). However, using an excuse (Scott and Lyman 1968), she removes the responsibility from the street dwellers. It is the street environment that makes people addicted or violent. Violence itself is justified as an act of self-defense, which is also accepted by society in some types of criminal cases.

It should also be noted that Vanessa distances herself from the homeless category by defending her thesis using the resource of impersonalization (who usually doesn't drink ends up drinking, who usually doesn't use drugs uses them (0.4) who is not violent $>$ becomes violent $<$ to defend themselves). Her thesis, which states that the streets, not the people, should be held responsible for the behavior of homeless people, goes on when Vanessa talks about her experience in the streets:

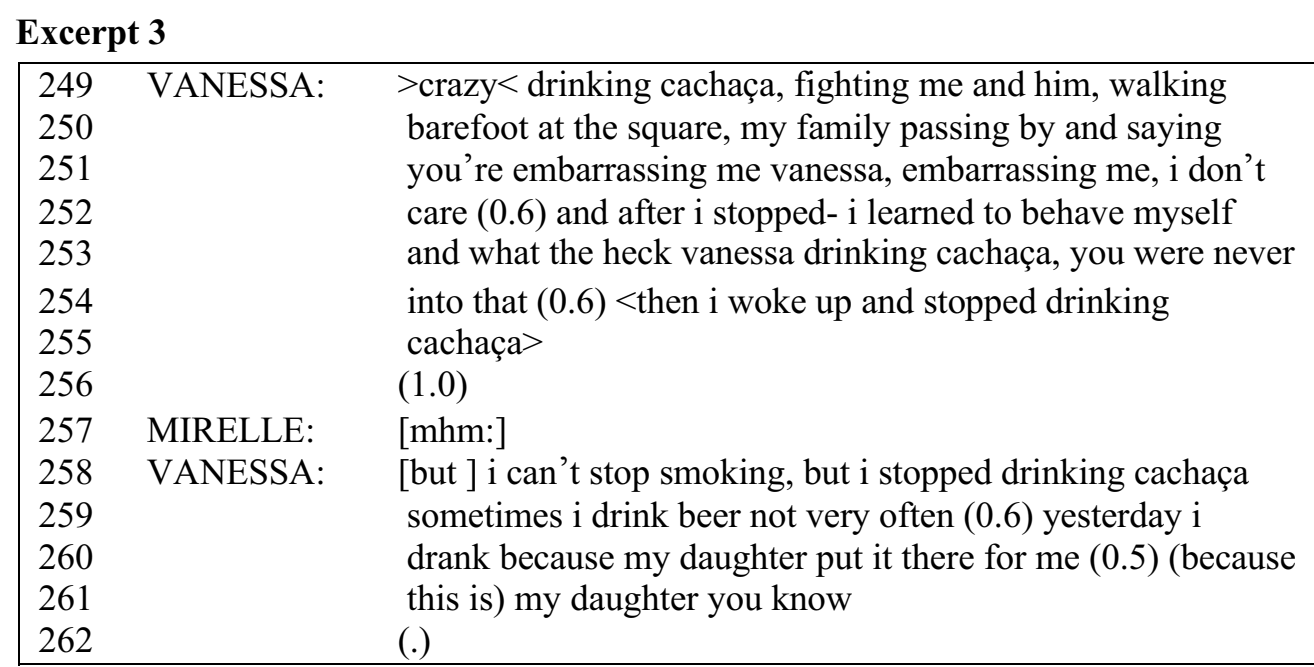

In this moment, Vanessa recognizes that her behavior confirms what common sense associates with the homeless category, as seen in lines 249-250 ( $>$ crazy $<$ drinking cachaça, fighting me and him, walking barefoot at the square). Afterwards, however, she endorses the thesis previously advocated. When projecting herself as a member of the "family" collection, invoking the voice of her sister through a reported speech, Vanessa 
points out the contrast between what she was and what she came to be. The turning point of her story is then established (and after i stopped - i learned to behave myself), which marks the refutation of the stigmatized identity that society gave her. Afterwards, Vanessa performs a talking back to these identities (and after i stopped - i learned to behave myself and what the heck vanessa drinking cachaça, you were never into that $(0.6)<$ then i woke up and stopped drinking cachaça $>$ ) in lines $252-255$.

Studies show that drinking is the most common means of socializing among the street population and that, to be accepted by their peers and endure the social suffering imposed by this reality, individuals tend to drink (Trubilhano 2011, Vieira, et al. 1994). To a certain extent, this result endorses the thesis whereby the streets are responsible for deviant behavior.

Another important point is that, when claiming what she considers to be her "true" identity, Vanessa only mentions socially accepted addictions, such as cigarettes and beer ([but] i can't stop smoking, but i stopped drinking cachaça sometimes i drink beer not very often (0.6)). The most radical talking back to her classification as "homeless" person (a category that she introduces) takes place in another thesis:

\section{Excerpt 4}

\begin{tabular}{|lll}
\hline 393 & VANESSA: $=>$ i don't know $<$ the name of that thing, it's museum right \\
394 & $(1.1)$ we've already slept there, we slept twenty days there \\
395 & $(0.9)$ you know $>>$ that $\uparrow<<$ who lives in the $\uparrow$ streets $(0.6)$ \\
396 & who was raised $>$ born $<$ and raised and do- copes $>$ very $<$ well \\
397 & in comparison with who is not used to it, who $>$ always $<$ had \\
398 & a home $($.$) a family (0.5){ }^{\circ}$ it's complicated ${ }^{\circ}(.){ }^{\circ}$ because ${ }^{\circ}$ \\
399 & $(1.3)$ i learned a lot living in the streets because i was a \\
400 & & person $(0.6)$ not him he was already raised in the streets \\
401 & & $()$. \\
402 & MIRELLE: & Mhm
\end{tabular}

Despite the fact that NPOs and the State use the expression "people who are in the streets" to refer to this demographic, in accordance with Decree $n^{\circ} 7.053$ of December 23, 2009, which outlines the national politics for this population, the narrator defends the thesis that there are two categories: homeless people and people who are in the streets. The central argument of this thesis is constructed on socialization. For her, homeless people are those who "belong to the streets", because they were born and raised in this environment; the other group is composed by those who "are in the streets" but have the experience of having a home and family, which makes it more difficult to adjust their identities to life in the streets (you know $>>$ that $\uparrow<<$ who lives in the $\uparrow$ streets (0.6) who was raised $>$ born $<$ and raised and do- copes $>$ very $<$ well in comparison with who is not used to it, who $>$ always $<$ had a home (.) a family (0.5) ${ }^{\circ}$ it's complicated ${ }^{\circ}$ ), lines 395398. According to her description, the first group is devoid of everything (affection, values, education, etc.), which would not be the case for her.

Through her storytelling, Vanessa shows how identities can be different. Regardless of that, when talking about her displacement to the streets, she projects herself as a member of the "family" collection and states that her deviant behavior is caused by the street environment. She shows knowledge about the stigmas, but refutes stigmatized identities by using talking back strategies such as accounts and impersonalization. 


\section{THE CONSTRUCTION OF MOTHERHOOD AND STIGMATIZED IDENTITIES}

Another interesting point for our analysis is the contrast that she establishes in the "mother" category. In the following excerpt, she describes her husband's mother (she categorizes the husband as "homeless"):

Excerpt 5

\begin{tabular}{|c|c|}
\hline 403 VANESSA: & you know his mother made them steal when he was small he \\
\hline 404 & never studied (0.8) he $\uparrow$ can’t write his full name $(0.5)$ \\
\hline 405 & correctly $(0.7)$ so $>$ he is already $<$ he was already raised \\
\hline 406 & in the streets for him it is, for him it is easy because \\
\hline 407 & he is already $>$ used $<$ to living in the streets (.) not \\
\hline 408 & for me it is difficult for me because i- when i met him \\
\hline 409 & $\mathrm{i}$ had my house (0.5) i had claudia who is older not his \\
\hline 410 & (0.8) then came the seven $(0.7)$ you know \\
\hline
\end{tabular}

Following her speech on the difference between her and her husband, she also mentions a stigmatized categorization of a mother who does not take care of the children, using them to earn money instead of enrolling them in school so they can learn how to read and write (lines 403-405). In contrast, when it comes to her performance as a mother, she projects herself as a different kind of mother.

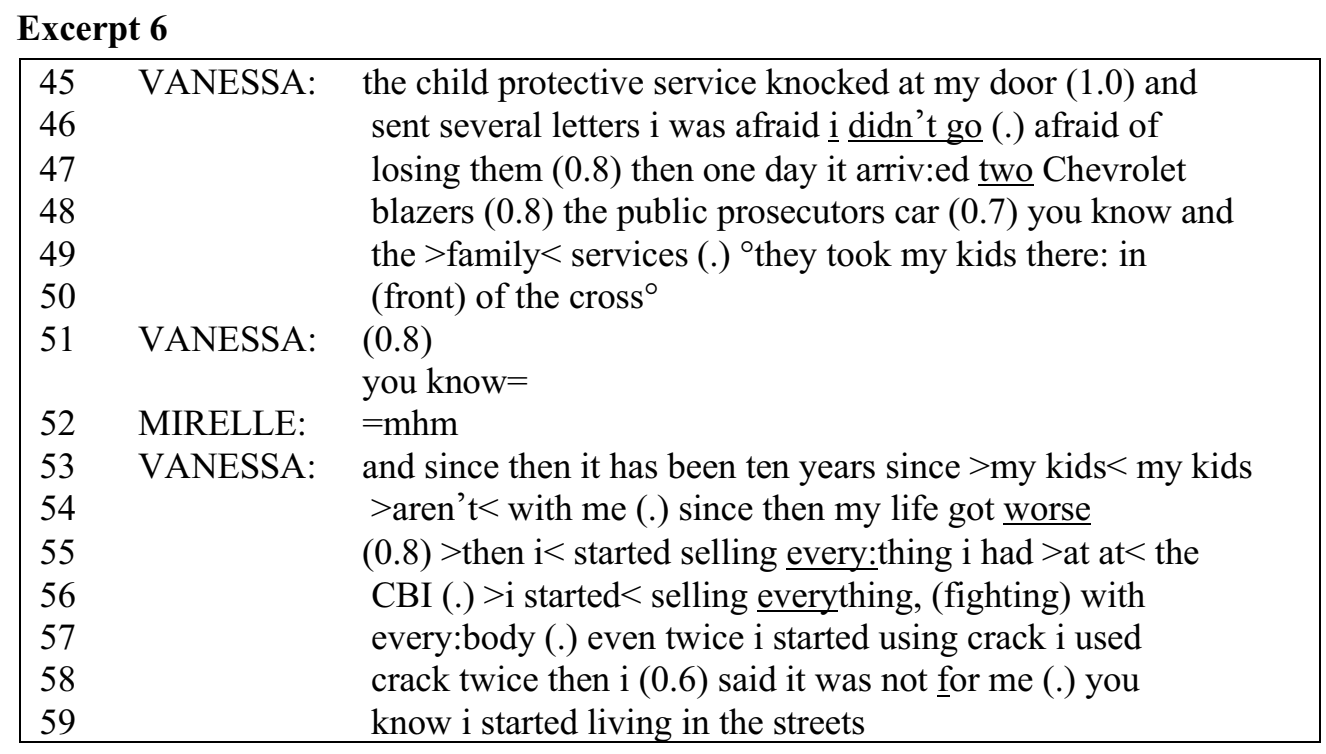

Vanessa uses an account (i didn't go (.) afraid of losing them (0.8)) in lines 46-47 to justify why she did not go to the Child Protective Services after receiving their letters. In addition, she argues that the loss of her children is a negative turning point in her life, which marks an increasingly larger decline (lines 53-59).

For most of the interview, Mirelle is a passive receptor, as the narrator does not need to shape her story based on the interviewer's answers. She keeps agreeing with the stories told by Vanessa by using continuers such as "mhm", 
Still projecting the "mother" identity, which follows the dominant discourse whereby children constitute the meaning of life, in another moment of her story Vanessa mentions her pregnancy as the turning point for her departure from the streets, as shown in Excerpt 7:

\section{Excerpt 7}

\begin{tabular}{|c|c|c|}
\hline 220 & VANESSA: & then as $i$ get the \\
\hline 221 & & social rent (1.3) i wanted to rent a house but $\mathrm{i}$ wanted god \\
\hline 222 & & to give me a ho- a reason for me to rent a house then god \\
\hline 223 & VANESSA: & gave me her $(0.6)$ she came $[[$ the daughter $]] \mathrm{i}$ asked for god \\
\hline 224 & & to change my life his way but in a way $\mathrm{i}$ can handle \\
\hline 225 & & $(1.3)$ \\
\hline 226 & VANESSA: & \\
\hline 227 & MIRELLE: & ${ }^{\circ} \mathrm{mhm}:{ }^{\circ}$ \\
\hline 228 & VANESSA: & you know then he gave me- luíza vitória \\
\hline 229 & & $(0.7)$ \\
\hline
\end{tabular}

Through her eighth pregnancy, Vanessa finds strength and sees the possibility of a new life, a new beginning, a departure from the streets, which is represented by the desire to rent a house (lines $220-225$ ). The house represents family, the return to the real identity advocated by her.

Motherhood, therefore, is seen as a type of redemption, in an association between the dominant discourse of motherhood and religious discourse. Now God is responsible for the change in her life and her departure from the streets. In the context of religious Christian discourse, the daughter is seen as having been sent by God (i wanted god to give me a ho- a reason for me to rent a house then god gave me her (0.6) she came [[the daughter]] i asked for god to change my life his way but in a way i can handle) in lines 222-224.

According to the normative discourse on motherhood, children should be the center of a mother's life, her reason to live. As shown in Excerpt 8, the new pregnancy also acts as a kind of symbolic rescue of the children whose custody was taken from her:

\section{Excerpt 8}

\begin{tabular}{|lll}
\hline 305 & VANESSA: & $=$ i can’t stand this life anymore $(0.5)$ \\
306 & & WITHOUT A CHILD because $>$ then $<($.$) ONE i$ can hug with \\
307 & & the love of one i remember it as- as the love of \\
308 & & {$[$ them] all } \\
{$[\ldots]$} & MIRELLE: & {$[\uparrow$ um: $]$} \\
471 & VANESSA: & through her] get the other ones i want my other \\
472 & & Children
\end{tabular}

Through her discourses, Vanessa characterizes different types of people living in the streets and confirms her belonging to the "mother" category as adjusted to the normative discourse of motherhood, which reinforces her status as a member of the "family" collection. 


\section{FINAL CONSIDERATIONS}

Vanessa's storytelling involves building an identity that distances herself from the dominant categorizations about those who live in the streets. Through different strategies of refutation, she projects herself as a member of another category. An important aspect in the refutation of these categorizations relates to the "mother" category, which becomes key in her story. It recalls the dominant discourse on motherhood which refuses categorizations of pregnant women and mothers living in the streets.

An important result of this study is drawing attention to the issue of category production by outsiders and by a member of the homeless category. As shown in the analysis, not all of them see themselves as homeless. Other categories may be identified when we listen to the voices of the social actors themselves.

This study also contributes to the advancement of studies about talking back to stigmatized identities, as well as to the knowledge about the diversity of identities of members of the same category. It also shows how certain dominant categories serve only as disseminators of biased inferences that do not necessarily correspond to reality.

Appendix 1. Transcription conventions ${ }^{4}$

\begin{tabular}{|l|l|}
\hline$(1.8)$ & Pause \\
\hline$()$. & Micropause \\
\hline$=$ & Speech immediately after the previous one \\
\hline$[$ Text $]$ & Overlapped speeches \\
\hline, & Continuous intonation \\
\hline$\uparrow$ text & Ascending syllable intonation \\
\hline$\downarrow$ text & Descending syllable intonation \\
\hline$\cdot$ & Descending turn intonation \\
\hline$?$ & Ascending turn intonation \\
\hline- & Abrupt interruption of speech \\
\hline$::$. & Sound stretching \\
\hline$>$ Text $<$ & Accelerated speech \\
\hline$>>$ Text $<<$ & Very accelerated speech \\
\hline$<$ Text $>$ & Slower speech \\
\hline$<<$ Text $>>$ & Much slower speech \\
\hline TEXT & Higher volume \\
\hline${ }^{\circ}$ text ${ }^{\circ}$ & Low volume \\
\hline${ }^{\circ}$ text ${ }^{\circ}$ & Very low volume \\
\hline Text & Stressed syllable, word or sound \\
\hline$($ Text $)$ & Transcriber was uncertain \\
\hline xxxx & Incomprehensible speech \\
\hline$[[$ Text $]]$ & Comments by the transcriber \\
\hline hhhh & Nasal laugh \\
\hline hahahehehihi & Laughter with vowel sound \\
\hline$\{\{$ laughing $\}$ text $\}$ & Turns or words pronounced while laughing \\
\hline. hhh & Audible inhaling \\
\hline & \\
\hline
\end{tabular}

(C) Maria do Carmo Leite de Oliveira, Carla Mirelle de Oliveira Matos Lisboa, 2017

${ }^{4}$ Model based on Jefferson's recommendations for transcription and adapted by the Talk-in-Interaction in Institutional and Non-Institutional Settings research group using markings suggested by the GAT2 document. In this journal, we replaced double round brackets by double square brackets, because this would better conform the norms of Russian pronunciation. 


\section{REFERENCES}

Badinter, E. (1980) L'amour en plus: Histoire de l'amour maternel (XVIIe-XXe siècle). Paris, France: Flammarion.

Brêtas, P. (2016, May 11) Aluguel social: governo do Rio corta benefício de 9 mil famílias removidas de áreas de risco. Jornal Extra. Available at: http:/extra.globo.com/noticias/economia/ aluguel-social-governo-do-rio-corta-beneficio-de-9-mil-familias-removidas-de-areas-de-risco20416214.html-ixzz4PAIvu8zr.

Denzin, N. K., \& Lincoln, Y. S. (2003) The Landscape of Qualitative Research: Theories and Issues. Thousand Oaks, CA: SAGE Publications.

Garcez, P. M. (2002) Transcrição como teoria: a identificação dos falantes como atividade analítica plena. In L. P. Moita lopes \& L. C. Bastos (eds.). Identidades: recortes multi e interdisciplinares. Campinas, SP: Mercado das Letras.

Garcez, P. M. (2008) A perspectiva da Análise da Conversa Etnometodológica sobre o uso da linguagem em interação social. In L. L. Loder \& N. M. Jung (eds.), Fala-em-interação social: introdução analise da conversa etnometodológica. Campinas, SP: Mercado de Letras, 17-38.

Garfinkel, H. (1967) Studies in ethnomethodology. Englewood Cliffs: Prentice-Hall.

Goffman, E. (1963) Stigma: notes on the management of spoiled identity. Englewood Cliffs: PrenticeHall.

Governo do Rio de Janeiro, \& Secretaria de Estado de Assistência Social e Direitos Humanos. (2016, May 11) Assistência Social e Direitos Humanos - Aluguel Social. Available at: http://www.rj.gov.br/web/seasdh/exibeconteudo?article-id=1519686.

Hall, S. (1992) The Question of Cultural Identity. In T. McGrew, S. Hall, \& D. Held (Cambridge: Polity Press. eds.), Modernity and its Futures: Understanding Modern Societies, Book IV, $273-316$.

Jefferson, G. (1974) Error Correction as an Interactional Resource. Language in Society, 3(2), 181199.

Juhila, K. (2004) Talking Back to Stigmatized Identities: Negotiation of Culturally Dominant Categorizations in Interviews with Shelter Residents. Qualitative Social Work, 3(3), 259-275.

Mandelbaum, J. (2013) Storytelling in conversation. In J. Sidnell \& T. Stivers (eds.), The handbook of conversation analysis (pp. 492-508). Oxford: Wiley-Blackwell.

Mishler, E. G. (1986) Research interviewing: context and narrative. Cambridge, Mass: Harvard University Press.

Morgan, S. (2000) 'Three Prisoners' Stories: Talking Back Through Autobiography'. In J. Batsleer \& B. Humphries (eds.) Welfare, Exclusion \& Political Agency. London: Routledge, 190-212.

Sacks, H. (1995) Lectures on Conversation, Volumes I and II Oxford: Wiley-Blackwell.

Scavone, L. (2001) A maternidade e o feminismo: diálogo com as ciências sociais. Cadernos Pagu, $16,137-150$.

Schegloff, E. A. (1997) "Narrative Analysis" Thirty Years Later. Journal of Narrative and Life History, 7(1-4), 97-106. doi: doi:10.1075/jnlh.7.11nar.

Schneider, B., \& Remillard, C. (2013) Caring about homelessness: how identity work maintains the stigma of homelessness. Text \& Talk, 33, 95-112.

Scott, M. B., \& Lyman, S. M. (1968) Accounts. American Sociological Review, 33(1), 46-62. doi: $10.2307 / 2092239$.

Sell, M., \& Ostermann, A. C. (2009) Análise de categorias de pertença (ACP) em estudos de linguagem e gênero: a (des)construção discursiva do homogêneo masculino. Alfa: Revista de Linguística, $53(1), 11-34$. 
Sidnell, J. (2010) Conversation Analysis: An Introduction. Oxford: Wiley Blackwell.

Silverman, D. (1998) Harvey Sacks: Social Science and Conversation Analysis. New York, NY: Oxford University Press.

Trubilhano, A. G. (2011) Rua dos bobos, número zero: As estratégias de sobrevivência de pessoas em situação de rua. Universidade Presbiteriana Mackenzie, São Paulo, Brazil [Thesis]. Available at: http://www.mackenzie.br/fileadmin/Graduacao/CCBS/Cursos/Psicologia/2012/BIBLIOT_DIG _LEVV/JUSTICA_E_CID/Amanda_Gongora_Trubilhano.pdf.

Vieira, M. A. d. C., Bezerra, E. M. R., \& Rosa, C. M. M. (1994) População de rua: quem é? Como vive? Como é vista? São Paulo, SP: Hucitec.

\title{
Article history:
}

Received: 20 January 2017

Revised: 17 February 2017

Accepted: 22 February 2017

\section{For citation:}

Oliveira, Maria do Carmo and Lisboa, Carla Mirelle (2017). Narratives about Displacement and Stigmatization of Identities. Russian Journal of Linguistics, 21 (2), 320-334.

\section{Bio note:}

Maria do Carmo Leite de Oliveira Professor at Pontifícia Universidade Católica do Rio de Janeiro (PUC-Rio). Research interests: Applied Linguistics, Language, Discourse Analysis, Pragmatics, Language Teaching. Contact information: e-mail: mcleitedeoliveira@gmail.com

Carla Mirelle de Oliveira Matos Lisboa Doctoral Student in the Post-Graduation Program in Language Studies at Pontifícia Universidade Católica do Rio de Janeiro (PUC-Rio) and volunteer at the Turma da Sopa non-profit organization in the city of Niterói, RJ. Research interests: Applied Linguistics, Language, Discourse Analysis, Pragmatics, Language Teaching. Contact information: e-mail: mirellematos@gmail.com

\section{Finance and Acknowledgements}

Maria do Carmo Leite de Oliveira would like to acknowledge the financial support given by the Brazilian Council — The National Scientific and Technological Research Council (CNPq) for research on organizational context.

Carla Mirelle de Oliveira Matos Lisboa would like to acknowledge the financial support given by Commission for the Improvement of Higher Education Personnel (CAPES) for her PhD Scholarship.

\section{НАРРАТИВЫ ОБ УТРАТЕ СОЦИАЛЬНОГО СТАТУСА И СТИГМАТИЗАЦИИ ИДЕНТИЧНОСТИ}

\author{
Мария до Кармо Льете де Оливейра, \\ Карла Мирель де Оливейра Матош Лисбоа
}

Католический Университет католическом университете Рио-де-Жанейро 225 Rua Marquês de São Vicente, 22453-900 Gávea, Puо-де-Жанейро, Бразилия

Потеря социального статуса людей, которые покидают свои дома, чтобы жить на улице, является одной из социальных драм, которые довольно типичны для больших городов. Несмотря на то, что эти люди образуют разнородную группу населения, общество видит их однородность, исходя 
из обобщенно негативного к ним отношения. В статье проводится анализ рассказа о потере социального статуса женщиной, которая в результате ливневых дождей лишилась своего дома и оказалась на улице со своими семью младшими детьми. На основе понятий о членстве в группе, социального клейма и в качестве опыта анализа авторы ставят перед собой цель исследовать, как бывшая бездомная отвергает попытки ее стигматизации, оправдывает себя, а также какую альтернативную идентичность она приписывает себе. Ее рассказ появился в контексте интервью, сделанного в рамках исследования историй жизни. Исследование показывает, что рассказчик пытается построить внятный для самого себя нарратив, принимая в оправдание себя систему убеждений, которые бы его структурировали и давали бы соответствующие объяснения событиям жизни. В результате она возлагает вину за девиантное поведение бездомных на уличное окружение, а также описывает свой статус через категорию матери как члена некой «семьи», порождая образы доминантного дискурса о материнстве как наивысшей самореализации женщины. В конечном итоге это исследование подчекивает, как важно знать нативные категории, то есть категории, созданные членами респондентской группы, но находящиеся в полном противоречии с категориями тех, кто в эту группу не входит.

Ключевые слова: конверсаиионный анализ, дискурс, бездомные, клеймо/стигма, идентичность, самооправдание, внутренняя потеря статуса, нарратив

\section{История статьи:}

Дата поступления в редакцию: 20 января 2017

Дата принятия к печати: 22 февраля 2017

\section{Для цитирования:}

Oliveira M., Lisboa C. Matos. Narratives about Displacement and Stigmatization of Identities // Вестник Российского университета дружбы народов. Серия: Лингвистика. 2017. Т. 21. № 2. C. 320-334.

\section{Сведения об авторе:}

Мария до Кармо Льете де Оливейра, доктор, профессор Католического университета Рио-деЖанейро (Бразилия). Научные интересы: прикладная лингвистика, общее языкознание, дискурс-анализ, прагматика, методика преподавания иностранных языков. Контактная информация: e-mail: mcleitedeoliveira@gmail.com

Карла Мирель де Оливейра Матош Лисбоа, аспирант Католического университета Рио-де-Жанейро (Бразилия). Научные интересы: прикладная лингвистика, общее языкознание, дискурсанализ, прагматика, методика преподавания иностранных языков. Контактная информация: e-mail: mirellematos@gmail.com

\section{Благодарности и финансирование}

Мария до Кармо Льете де Оливейра выражает благодарность "Brazilian Council — The National Scientific and Technological Research Council (CNPq)" за оказанную финансовую поддержку при проведении данного исследования.

Карла Мирель де Оливейра Матош Лисбоа выражает благодарность “Commission for the Improvement of Higher Education Personnel” (CAPES) за предоставление PhD стипендии. 